\title{
Women and Land Tenure Security: The Nigerian Experience
}

\author{
Remi Adeyemo ${ }^{1, ~ *, ~ M i c h a e l ~ K i r k ², ~ O l a i t a n ~ O l u s e g u n ~}{ }^{3}$ \\ ${ }^{1}$ Department of Agricultural Economics, Obafemi Awolowo University, Ile-Ife, Nigeria \\ ${ }^{2}$ School of Business and Economics, Marburg University, Marburg, Germany \\ ${ }^{3}$ Department of Jurisprudence \& Private Law, Obafemi Awolowo University, Ile-Ife, Nigeria \\ Email address: \\ radeyemo2011@yahoo.com(R. Adeyemo) \\ ${ }^{*}$ Corresponding author
}

To cite this article:

Remi Adeyemo, Michael Kirk, Olaitan Olusegun. Women and Land Tenure Security: The Nigerian Experience. International Journal of Agricultural Economics. Vol. 4, No. 2, 2019, pp. 41-47. doi: 10.11648/j.ijae.20190402.11

Received: January 29, 2019; Accepted: March 11, 2019; Published: March 27, 2019

\begin{abstract}
This study investigated the farm level efficiency and farm income among tenure secured and unsecured women farmers in Osun State, Nigeria. Structured questionnaires were used to obtain information from one hundred and fifty farmers. The data were analysed using descriptive statistics, stochastic frontier and farm budget analyses. Results from the farm budget analysis showed that women with secured land tenure generated higher income which was one hundred and fifty four thousand naira while that of women with unsecured land tenure was about eighty two thousand naira. Additional analysis revealed that land tenure secured women farmers were more efficient (64\%) than their counterparts with unsecured tenure (48\%). There was an overwhelming affirmation arising from the study which confirmed that women with tenure security were better off with respect to farm efficiency and farm income than women with unsecured tenure.
\end{abstract}

Keywords: Land, Tenure, Women, Gender and Efficiency, Rights, Food

\section{Introduction}

No region of the world has developed a diverse modern economy without first establishing a successful agricultural sector. Providing food on small family farms has always been at the heart of the African experience. Now, we are embracing the agriculture of our future. Agriculture is beginning to enrich Africa with a series of compelling economic opportunities on and off the farm that can be tapped across the continent to set Africa free from poverty and over reliance on oil.

The challenge of addressing global food security is greatest in Africa where close to 300 million are malnourished [1]. It is the only region of the world where the proportion of the population that is food insecure has increased. Africa holds the key for feeding the nine million people that will be in the planet earth by 2050 . Africa sits on $65 \%$ of the uncultivated arable land left in the world, so what Africa does with agriculture will determine the future of food in the world [2].
In 2017, the German Development Minister presented a Marshall Plan with Africa as part of German G20, the minister indicated in his presentation that women are the drivers of achieving sustainable development goals agenda [3]. The Food Agricultural Organization has also documented that if women in agriculture had the same opportunities as men, yields could be increased by 20 to $30 \%$ and economic performance could be enhanced by $2.5 \%$ to $4 \%$ while the number of people suffering from hunger could be reduced by 12 to $17 \%$ [4]. It is not a secret that farming is becoming a predominantly female sector, women are found performing duties on the farm and in the case where their husbands have migrated in search for wage labour, women have been found clearing bushes and making heaps. Women now constitute the majority of small farmers managing a large part of the farming activities on a daily basis.

There is no agriculture without land. Nevertheless access to land and use of production resources such as land are often dictated by a complex set of rights and obligations reflecting social and religious norms which often act as disincentives to women farmers in terms of farm production in many 
developing countries of the world. Women have limited decision making power and have had to depend on men for user rights which are easily lost, if they become widowed or divorced. Insecurity of land tenure discourages women from investing time and resources in sustainable farming practices and consequently reduces their level of farm income.

In Nigeria, the concerned in achieving the United Nations Millennium Development Goals of gender equality and women empowerment, that is, the government, policy makers and international donor agencies, have in the last few years increasingly stressed the importance of secure land tenure for women and the need to support access to land for women in order to enhance their level of economic empowerment through agricultural production [5].

Secured property rights give sufficient incentives to farmers to increase their efficiencies in terms of productivity and ensure environmental sustainability. It is natural that without secured property rights, farmers do not feel emotional attachment to the land they cultivate, do not invest in land development and will not use input efficiently. There is an agreement in the literature that secure individual land rights will increase incentives to undertake enhancing land related investment $[6,7]$. However, an important question is whether tenure security actually influences the level of farm productivity among women farmers. It is therefore hypothesised that women farmers with secured land tenure will be more efficient with higher farm income than those with non-secured land tenure.

Objective and Policy Relevance

The objective of this research was to compare the farm level efficiency and farm income among tenured secured and unsecured women farmers, with a view to detect the differences among the two categories and increase agricultural productivity among women farmers. The research would be relevant for the development of gender advocacy programs on access to productive resources.

\section{Methodology}

\subsection{Study Area}

The study was carried out in Osun State of Nigeria. Osun State is located in the South-western part of the country. It covers an area of approximately 14,875 square kilometres and shares common boundaries with Kwara, Oyo, Ekiti and Ondo States. The indigenes of the State belong to the Yoruba tribe but non-indigenes from all parts of Nigeria and foreigners reside in the state. The major crops grown in the State are cassava, maize, vegetables, cocoa, oil palm and rice. This implies that the climate in the State favours both arable and non-arable crops. The State experiences two major seasons, the dry and rainy seasons, with August break during the rainy season. The annual temperature varies from 21.1 to 31.1 Celsius, while annual rainfall is within the range of 800 $\mathrm{mm}$ in the dry savannah agro-ecology, to $1500 \mathrm{~mm}$ in the rain forest belt. Land tenure arrangement is still predominant in the State.

\subsection{Sampling Technique}

Farm activities was limited to arable crop production for ease of analysis. Purposive sampling technique was used to select the villages and a stratified random sampling technique was used to select the 83 tenured non-secured and 67 tenure secured women farmers. The rationale behind the selection of uneven number of respondents in the two categories is based on their uneven population. Structured questionnaires were employed, to collect information from one hundred and fifty women farmers within the state. The collected data were related to farmers' socio-economic characteristics such as age, years of schooling, marital status, farm size as well as quantities and prices of various inputs used and output produced.

\subsection{Method of Data Analysis}

\subsubsection{Descriptive Statistics}

Descriptive statistics was used to describe the socioeconomic characteristics of the respondents such as age, years spent in school, household size among others.

\subsubsection{Stochastic Frontier Production Function (SFPF)}

SFPF was used as a measure of productivity to compare farm level efficiency among the two categories (tenure secured and non-secured) of women farmers [8;9].

The Model was specified as presented in equation below:

$$
Q_{1}=\beta_{0}+\beta_{1}+\left(V_{1}-U_{1}\right)
$$

The above equation was transformed and presented in equation (2):

$$
\operatorname{In} Y=\beta_{0}+\beta_{1} \operatorname{In} X_{1}+\beta_{2} \operatorname{In} X_{2}+\beta_{3} \operatorname{In} X_{3}+\beta_{4} \operatorname{In} X_{4}+V_{i}-U_{i}
$$

Where: $I n=$ Natural logarithm.

$Y_{i}=$ Total farm output $(\mathrm{kg} / \mathrm{ha})$.

$X_{1}=$ Planting Materials (Stem Cuttings) $(\mathrm{kg} / \mathrm{ha})$

$X_{2}=$ Labour Used (man-days)

$X_{3}=$ Chemical $(\mathrm{kg} / \mathrm{ha})$

$X_{4}=$ Farm Size (ha)

$\beta_{0}=$ Intercept and $\beta_{1}, \beta_{2}, \beta_{3}, \beta_{4}=$ Parameters to be estimated.

$V_{1}$ is a random error which accounts for the random variations in output value by factors which are beyond the control of the farmers such as disease outbreak, weather, measurement errors, etc., and it is assumed to be independently and identically distributed $\left(V_{1} \sim 0, \sigma^{2}\right)$ and independent of $U_{i}$. $U_{i}$ is a non-negative variable(s) associated with technical inefficiency in production and it is assumed to be independently and identically distributed as half normal, $\left(U_{1} \sim 0, \sigma^{2}\right)$.

In order to determine the factors that contributed directly to technical inefficiency, equation (3) was estimated and jointly used with the stochastic models:

$$
T E=+Z_{1}+Z_{2}+Z_{3}++Z_{4}+\cdots+Z_{9}
$$

Where $T E=$ Technical efficiency of $i$-th farmer. $Z_{1}=$ Age (years). 
$Z_{2}=$ Households size (\#).

$Z_{3}=$ Farming experience (years).

$Z_{4}=$ Education (years).

$Z_{5}=$ Access to credit $(1=$ yes; $0=$ no $)$.

$Z_{6}=$ Membership of association $(1=$ yes; $0=$ no).

$Z_{7}=$ Extension contact $(1=$ yes; $0=$ no $)$.

$Z_{8}=$ off- farm employment $(1=$ yes; $0=$ no $)$.

$Z_{9}=$ Rent paid on land used ( $)$.

$\alpha_{0}=$ Intercept.

$\alpha_{1}, \ldots, \alpha_{16}=$ parameters to be estimated.

The maximum likelihood estimates (MLEs) of the parameters in the stochastic frontier production function (SFPF) model defined by equation (2) given the specification for the technical inefficiency effect defined by equation (3) were obtained. The unknown parameters of the stochastic frontiers and the inefficiency effects were estimated simultaneously.

\subsubsection{Farm Budget Analysis}

Farm budget analysis was used to analyse the costs and returns to production, in order to examine and compare the level of farm income among the tenure secured and nontenure-secured women farmers in the study area. The gross margin (GM) is the excess of returns over variable costs of production. Total revenue would be taken as the product of price per unit and quantity of various crops produced by the farm households. Products are sold at different markets with different prices. However, we used the average prices in our computation. Input costs would be valued at prices paid by the farmers and the gross margin would be calculated using the formula presented by equation (4):

$$
G M_{i}=\left(\sum T R_{i}-\sum T V C_{i}\right)
$$

Where:

$G M_{i}=$ Gross margin of ith farm household in naira per hectare (N/ha),

$T R_{i}=$ Total revenue of ith farm household in naira per hectare [Price $(\mathrm{P}) \times$ Quantity $(\mathrm{Q})]$, and

$T V C_{i}=$ Total variable cost of ith farm household in naira per hectare $(\mathrm{N} / \mathrm{ha})$.

\section{Results and Discussion}

\subsection{Socio-economic Characteristics of Arable Women Farmers}

The socio-economic characteristics of women farmers by tenure security were shown in Table 1. There was no significant difference between the mean age of tenure secured women farmers $(45 \pm 10$ years) and tenure unsecured women farmers ( $43 \pm 9$ years). Similarly, there was no significant difference between the mean years in schooling of tenure secured women farmers $(10.1 \pm 3.9$ years $)$ and tenure unsecured women farmer $(10.0 \pm 3.9$ years $)$. However, there was a significant difference $(\mathrm{p}<0.0)$ between the farm size of tenure secured women farmers $(1.91 \pm 1.68 \mathrm{ha})$ and the tenure unsecured women farmers $(1.27 \pm 1.17 \mathrm{ha})$. This suggests that the tenure secured women farmers have larger farms than the tenure unsecured women farmers. Similarly, t-test showed a significant difference $(p<0.01)$ between the years of farming experience of tenure secured women farmers $(23.44 \pm 10.26$ years) and the tenure unsecured women farmers $(19.35 \pm 12.17$ years). This suggests that the tenure secured women farmers have many years of experience in farming than the tenure unsecured women farmers. Also, there was a significant difference between the mean household size of the tenure secured women farmers ( $6 \pm 3$ persons $)$ and that of the tenure unsecured women farmers ( $7 \pm 3$ persons) at $p \leq 0.05$. This suggests that the tenure unsecured women farmers have larger households than the tenure secured women farmers. There was no significant difference between the mean labour cost per hectare of tenure secured women farmers, ( $\$ 38785 \pm 25752$ ) and tenure unsecured women farmers ( $\$ 4683 \pm 24199)$. There was however a significant difference $(\mathrm{p}<0.01)$ between the cost of other inputs per hectare of tenure secured women farmers ( $111046 \pm 102997)$ and the tenure unsecured women farmers $(77501 \pm 59783)$. This suggests that the tenure secured women farmers have larger to spend on their production more than the tenure unsecured women farmers.

Table 1. Socio-economic characteristics of the women farmers.

\begin{tabular}{llll}
\hline Variables & Secured Tenure & Unsecured Tenure & T-test \\
\hline Age (years) & $45.35(10.05)$ & $43.238(9.879)$ & 1.300 \\
Years in Schooling & $10.107(3.920)$ & $10.074(3.92)$ & 0.51 \\
Household Size (\#) & $5.92(2.58)$ & $7.035(2.951)$ & $2.426^{* *}$ \\
Farming Experience (years) & $23.447(10.257)$ & $19.357(12.178)$ & $2.197 * *$ \\
Farm Size (ha) & $1.911(1.683)$ & $1.2752(1.1712)$ & $2.357 * *$ \\
Labour Cost (N/ha) & $38,785(25,752)$ & $44,683(24,179)$ & 1.24 \\
Cost of other inputs (N/ha) & $111,046(102,997)$ & $77,501(59,783)$ & $2.065^{* *}$ \\
Married (\% yes) & 91.7 & 79.1 & 17.9 \\
Widowed (\% yes) & 7.1 & & \\
\hline
\end{tabular}

Note: Figures in parentheses () are standard deviations; ** Significant at 5\%.

\subsection{Profitability of Arable Production Among Tenure Secured and Tenure Unsecured Women}

The results of the cost and returns/ha to women farmers (both tenure secured and unsecured) in the study area were presented in Table 2. The average revenue of tenure secured women farmers $(\mathrm{N} 319,950)$ was more than that of the tenure unsecured women farmers ( $\$ 230,995)$. The average variable cost of tenure secured women farmers ( 141,973) was more than that of the tenure unsecured women farmers ( 125,543$)$. 
Also, the fixed cost of tenure secured women farmers ( $\$ 24,263$ ) were more than that of the tenure unsecured women farmers $(23,535)$. The tenure secured women farmers have an average cost of 151,237 while that of the tenure unsecured women farmers was 149,078 . The gross margin of tenure secured women farmers was estimated to be N177, 976 which was higher than that of the tenure unsecured women farmers $(105,452)$. Furthermore, the average net income (revenue) of the tenure secured women farmers was estimated to be 153,713 , while that of the tenure unsecured women farmers was $\$ 81,917$. This revealed that the tenure secured women farmers were more profitable than the tenure unsecured women farmers in the study area.

Profitability indices revealed that the tenure secured women farmers had benefit cost ratio of $\$ 2.116$ which was higher than that of the tenure unsecured women farmers ( 1.549). The tenure secured women farmers had labour efficiency of 8.249 which was higher than that of the tenure unsecured women farmers ( $\$ 5.170)$. Similarly, the return per naira of tenure secured women farmers ( 6.335 ) was higher than that of the tenure unsecured women farmers ( 33.481 ). All the measures of performance indicated that tenure secured women farmers were viable and profitable in their production than tenure unsecured women farmers in the study area.

Table 2. Profitability of arable production among tenure secured and tenure unsecured women farmers.

\begin{tabular}{lll}
\hline Variables & $\begin{array}{l}\text { Tenure } \\
\text { unsecured } \\
\text { women (N) }\end{array}$ & $\begin{array}{l}\text { Tenure } \\
\text { secured } \\
\text { women (N) }\end{array}$ \\
\hline Revenue & $230,995.9$ & $319,950.6$ \\
Cost on labour & $44,683.53$ & $38,785.07$ \\
Transport cost & $3,509.412$ & $4,157.463$ \\
Fertilizer cost & $2,294.118$ & $4,365.672$ \\
Herbicide cost & $10,616.47$ & 12,900 \\
Agrochemical cost & $7,41.176$ & $4,365.672$ \\
Planting material cost & $63,698.82$ & 77,400 \\
Total variable cost & $125,543.526$ & $141,973.877$ \\
Gross margin $(\mathrm{GM})=$ TR-TVC & $105,452.374$ & $177,976.723$ \\
Fixed cost & & \\
Rent on land & 10,000 & 15,000 \\
Depreciation cost on implement & $4,804.002$ & $4,462.595$ \\
Depreciation cost on processing & $8,731.059$ & $4,801.045$ \\
Total fixed cost & $23,535.061$ & $24,263.64$ \\
Total cost & $149,078.587$ & $151,237.517$ \\
Net income & $81,917.309$ & $153,713.08$ \\
Profitability & & \\
Return per Naira & 3.481 & 6.335 \\
Operating Expense ratio & 0.457 & 0.444 \\
Benefit cost ratio & 1.549 & 2.116 \\
Labour efficiency & 5.170 & 8.249 \\
\hline
\end{tabular}

\subsection{Determinants of Productivity Among Tenure Secured and Tenure Unsecured Women}

The results of the estimates of the parameters of the stochastic frontier and the inefficiency model were presented in Table 3.

For tenure unsecured women farmers, the log likelihood of model was significant $(\mathrm{P}=0.0000)$ suggesting strong explanatory power. The average technical efficiency was
$48 \%$. It implies that on the average, the tenure unsecured women farmers were able to obtain just $48 \%$ of their potential output from a given sets of inputs available to them. This indicates that tenure unsecured women farmers were not productive and efficient with respect to the available set of inputs at the time of study. This implies that a highly significant amount of output is lost from their production.

The efficiency model revealed that the coefficient of total cost $(0.230)$ has positive sign and was statistically significant at $1 \%$. This implies that an increase in the total cost by $\# 1$ would increase the farm's technical efficiency by 0.230 units. Also, the coefficient of labour use (0.069) has positive sign and was statistically significant at $1 \%$. This implies that an increase in the labour use by one man-day would increase the farm's technical efficiency by 0.069 units. Similarly, the coefficient of farm size (1.038) has positive sign and was statistically significant at $1 \%$. This suggests that an increase in the farm size by one hectare would increase the farm's technical efficiency by 1.038 units. The inefficiency model revealed that the coefficient of age $(-8.169)$ has negative sign and was statistically significant at $10 \%$. This implies that an increase in the age by a year would decrease the farm's technical inefficiency by 8.169 units. Also, the coefficient of membership of association (-1.080) has negative sign and was statistically significant at $1 \%$. This implies that membership of association would decrease the farm's technical inefficiency by 1.080 units. Similarly, the coefficient of access to credit $(-1.439)$ has negative sign and was statistically significant at $1 \%$. This implies an increase access to credit by $\$ 1$ would decrease the farm's technical inefficiency by 8.169 units. This result corroborates the assertion made by $[10 ; 11]$.

For tenure secured women farmers, the log likelihood of model was significant $(\mathrm{P}=0.0000)$ suggesting strong explanatory power. The average technical efficiency was $64 \%$. It implies that on the average, the tenure secured women farmers were able to obtain $64 \%$ of their potential output from a given sets of inputs available to them. This indicates that they are productive and efficient more than tenure unsecured women farmers in study area.

The efficiency model revealed that the coefficient of total cost $(0.262)$ has positive sign and was statistically significant at $1 \%$. This implies that an increase in the total cost by $\$ 1$ would increase the farm's technical efficiency by 0.262 units. Also, the coefficient of chemicals $(0.260)$ has positive sign and was statistically significant at $1 \%$. This implies that an increase in the chemicals by one litre would increase the farm's technical efficiency by 0.260 units. Similarly, the coefficient of farm size (1.003) has positive sign and was statistically significant at $1 \%$. This implies that an increase in the farm size by one hectare would increase the farm's technical efficiency by 1.038 units.

The inefficiency model revealed that the coefficient of age $(-1.657)$ has negative sign and was statistically significant at $5 \%$. This implies that an increase in the age by a year would decrease the farm's technical inefficiency by 1.657 units. The coefficient of household size $(-1.816)$ has negative sign and 
was statistically significant at $5 \%$. This implies that an increase in the household size by a person would decrease the farm's technical inefficiency by 1.816 units. The coefficient of years spent in school $(-2.126)$ has negative sign and was statistically significant at $5 \%$. This implies that an increase in years spent in school by a year would decrease the farm's technical inefficiency by 2.126 units. The coefficient of years of farming experience $(-2.042)$ has negative sign and was statistically significant at $1 \%$. This implies that an increase in years of farming experience by a year would decrease the farm's technical inefficiency by 2.042 units. The coefficient of access to credit $(-0.826)$ has negative sign and was statistically significant at $5 \%$. This implies that an increase access to credit by $\$ 1$ would decrease the farm's technical inefficiency by 0.826 units. The coefficient of rent paid on land (-0.188) has negative sign and was statistically significant at 5\%. This implies that an increase in rent paid on land by $\$ 1$ would decrease the farm's technical inefficiency by 0.188 units. This result corroborates the findings of [12-14].

Table 3. Determinants of productivity among tenure secured and tenure unsecured women.

\begin{tabular}{|c|c|c|c|c|}
\hline \multirow{2}{*}{$\begin{array}{l}\text { Efficiency } \\
\text { Variables } \\
\end{array}$} & \multicolumn{2}{|c|}{ Tenure unsecured women. } & \multicolumn{2}{|c|}{ Tenure secured women. } \\
\hline & Coefficient & T-test & Coefficient & T-test \\
\hline Total cost & 0.230 & $3.49 * * *$ & 0.2625 & $2.53 * * *$ \\
\hline Labour use & 0.069 & $2.62 * * *$ & -0.062 & -0.80 \\
\hline Farm size & 1.038 & $12.76^{* * *}$ & 1.003 & $23.51 * * *$ \\
\hline Chemicals & 0.017 & 0.31 & 0.260 & $4.64 * * *$ \\
\hline Constant & 9.630 & $9.43 * * *$ & 7.913 & $7.14 * * *$ \\
\hline Inefficiency model & \multicolumn{2}{|c|}{ Tenure unsecured women. } & \multicolumn{2}{|c|}{ Tenure secured women. } \\
\hline Variables & Coefficient & T-test & Coefficient & T-test \\
\hline Age & -8.169 & $-1.72 *$ & -1.657 & $-2.07 * *$ \\
\hline Household & 0.449 & 0.21 & -1.816 & $-2.45 * *$ \\
\hline Farming experience & 3.418 & 1.17 & -2.042 & $-2.96 * * *$ \\
\hline Education & 3.069 & 1.09 & -2.126 & $-2.11 * *$ \\
\hline Membership of association & -1.080 & $-3.51 * * *$ & 1.559 & 0.06 \\
\hline Extension visit & 2.339 & 0.87 & 3.391 & 0.12 \\
\hline Off farm employment & 1.189 & 0.61 & 0.270 & 0.03 \\
\hline Access to credit & -1.439 & $-2.25 * *$ & -0.826 & $-2.09 * *$ \\
\hline Rent paid on land & 0.135 & 0.30 & -0.188 & $-2.34 * *$ \\
\hline Constant & 3.611 & $3.53 * * *$ & 8.676 & $8.26 * * *$ \\
\hline Mean efficiency & 0.48 & & 0.64 & \\
\hline Log likelihood & 64.191 & & 39.632 & \\
\hline Prob >chi2 & 0.000 & & 0.0000 & \\
\hline
\end{tabular}

$(* * *)=$ significant at $1 \%,(* *)=$ significant at $5 \%,(*)=$ significant at $10 \%$ Figure in parentheses represents $t$ ratio value.

Source: Field survey, 2018.

\subsection{Legal Implications of the Access of Women to Land Tenure Security in Nigeria}

Nigeria practices a patriarchal system, which prohibits the inheritance of real property by women. Women are thus deprived of their right to inherit their husband's property, based on the belief that she is not the family's blood descendant [15]. This practice was reiterated in the case of Davies $v$ Davies (1929) 2 NLR 79, 80), where it was held that the transfer of property is conditional upon blood relations under native law and custom. This position has however been overturned through constitutional and human rights instruments, even though the practice persists in some parts of Nigeria [15].

With respect to international laws, the 1979 Convention on the Elimination of All Forms of Discrimination against Women (CEDAW), which is the most comprehensive international agreement on the basic human rights of women, prohibits all forms of discrimination based on sex, and notes the equal rights of both men and women in all areas of life. More specifically, Article 14 (2)(g) provides that States parties to the Convention shall ensure that women in rural areas benefit from rural development by granting these women 'access to agricultural credit and loans, marketing facilities, appropriate technology and equal treatment in land and agrarian reform as well as in land resettlement schemes'. Article 16(h) also protects women in all issues relating to marriage and family relations, by mandating States to take all necessary measures to eliminate discrimination against them by making the same rights available for both men and women in respect of the 'ownership, acquisition, management, administration, enjoyment and disposition of property'. Nigeria became a State party to the Convention by ratifying it in 1985.

The 2003 Protocol to the African Charter on Human and Peoples' Rights on the Rights of Women in Africa (Maputo Protocol), provides significant protection for women with respect to their access to land. Article 15 imposes a legal obligation on States that are parties to the Protocol to provide women with access to land, as a means of enjoying their right to food security. Moreover, Article 19 guarantees the existence of the right of women to enjoy sustainable development. To enjoy this right, States are to 'promote women's access and control over productive resources such as land and guarantee their right to property'. In 2009, the Heads of States and Government of the African Union, met in Sirte, Libyan Arab Jamahiriya, to develop and implement land policies in African countries. The result of their meeting 
was the "Declaration on Land Issues and Challenges in Africa", in which they resolved to ensure that land laws promote equitable access to land and related resources, as well as, strengthen security of land tenure for women [16]. Nigeria has also adopted this protocol.

At the Fourth World Conference on Women in September 1995, the Beijing Declaration and Platform for Action was adopted for the purpose of advancing the goals of equality, development and peace for all women, as well as the promotion of their rights. Article 35 of the Beijing Declaration enjoins States to provide equal access to land for both men and women, so as to advance and empower women and girls. The Declaration, to which Nigeria is a signatory, notes that women's poverty and sexual exploitation is caused by lack of access to economic resources, such as land ownership and inheritance. Thus, in developing countries especially, the productive capacity, income, education and health care of women, should be improved through access to land, capital, resources, technology, among others. The right of women to full and equal access to economic resources, including the right to inheritance and to ownership of land should be promoted through legislation and administrative reforms.

The "Commission on Human Rights resolution 2000/13, Women's equal ownership of, access to and control over land and the equal rights to own property and to adequate housing", which was adopted in 2000, recognizes that laws, policies, customs and traditions that prevent women from owning and inheriting land, property and housing, are discriminatory and may contribute to the feminization of poverty.

As regards Nigeria, the Constitution of the Federal Republic of Nigeria, 1999, protects all citizens from discrimination on the basis of ethnicity, place of origin, sex, religion and political opinions. Section 43 of the Constitution, also provides that 'every citizen of Nigeria shall have the right to acquire and own immovable property anywhere in Nigeria'. Furthermore, section 1 of the Nigerian 1978 Land Use Act vested all land in all the states of the Federation, to the governors of such states. All persons are to apply for either a customary certificate of occupancy or statutory certificate of occupancy. This process is however cumbersome, costly, and limits the capacity of women to land tenure security.

\section{Conclusion}

This study was undertaken in order to show the differences in the farm level efficiency and farm income among secured land tenure women and unsecured land tenure women farmers with a view to increase productivity among women farmers in the study areas.

The results revealed that return per naira value accruing to secured land tenure women was higher than that of unsecured tenure women. The women farmers with secured land tenure had higher value of technical efficiency than women with unsecured land tenure. The implication of this research result, is that land tenure is a major determinant of the level of farm efficiency and farm income among the women farmers in the areas of study, which may in general, apply to other areas in Nigeria.

It is obvious that the rights of women to land tenure has been established in international instrument, some of which Nigeria is a signatory to. These international instruments are however not enforceable in Nigeria due to the fact that they have not been domesticated by the National Assembly, as specified in section 12 of the 1999 constitution. They have to be domesticated so as to bring about their effectiveness. Although Declarations are not binding but serve as a form of guide to countries to use as a template for decision making and enactment of laws, policies and action plans. In order for unsecured women to become tenured secured and more efficient, a land policy which is based on the principle of gender equality with women involved in dialogue and formulation of such policies will further increase the productivity of women.

\section{Acknowledgements}

The authors acknowledge with thanks the data for this study collected by messers Kehinde Ayodeji, Oladokun Jide and Kolawole Mathew.

\section{References}

[1] FAO (2017) The Future of Food and Agriculture: Trends and Challenges, FAO, Rome.

[2] World Bank (2015) Global Monitoring Report 2014/2015, Ending Poverty and sharing Prosperity. World Bank Group, Washington DC.

[3] D $+C$ (2017) Global Agenda and Programmes for the poorest of the poor. Vol 44 pgs. $10 \& 21$.

[4] FAO (2011) The Role of Women in Agriculture Available from $\mathrm{http} / / \mathrm{www}$. fao/docrep/113/am307e/eopdf

[5] Adeyemo R (2014) Strengthening institutions for food Security in West Africa Sub Region: Implication for Nigeria. Faculty Published Seminar Series, Obafemi Awolowo University, Ile-Ife, 26pgs.

[6] World Bank (2015) The Cost of the Gender Gap in Agricultural productivity in Malawi, Tanzania and Uganda, World Bank Group Working Paper, Washington DC.

[7] Adeyemo R, Kirk M, and Ogunleye S (2015) Women Access to Land: The Compatibility of Property Rights on the Farming Activities of Women in Rice Producing Areas of Osun State, Nigeria. International Journal of Research in Agriculture and Forestry. 2 (10) 34-42.

[8] Coelli, T. J. (1995). 'Estimators and Hypothesis Test for a Stochastic Frontier Function' A Monte Carlo Analysis Journal of Productivity Analysis 6 (4): 247-268.

[9] Coelli, T. J. (1996). A Guide to Frontier Version 4.1: A computer Programmes for Stochastic Frontier Production and Cost Function Estimation. Mimeo- Department of Econometrics, University of New-England Arimidale. 
[10] Adewuyi, S. A. (2002), "Resource Use Productivity in Food Crop Production In Kwara State, Nigeria." PhD Thesis, Department of Agricultural Economics University of Ibadan, Ibadan.

[11] Masterson, T. (2007), Productivity, Technical Efficiency and Farm Size in Paraguayan Agriculture. The Levy Economics Institute Working Paper No. 490.

[12] Adejoh, S. D. (2009), "Analysis of Production Efficiency and Profitability of Yam-Based Production Systems in Ijunmu LGA of Kogi State." MSc thesis, Department of Agricultural Economics and Extension, Ahmadu-Bello University, Zaria.
[13] Adeyemo, R., J. T. O. Oke, and A. A. Akinola (2010), "Economic Efficiency of Small Scale Farmers in Ogun State, Nigeria", Tropicultura 28 (2).

[14] Oluwatosin, F. M. (2011), "Measuring Technical Efficiency of Yam Farmers in Nigeria: A Stochastic Parametric Approach." Agricultural Journals, 6 (2).

[15] Taiwo A. (2016), “The Nigerian Land Law” (2 ${ }^{\text {nd }}$ Ed, Princeton and Associates Publishing Co. Ltd.).

[16] Heinrich Boll Stiftung, (2013) 'Women and Land Rights: Questions of Access, Ownership and Control' (Heinrich Boll Foundation, Southern Africa). 